\title{
PHARMACOLOGICAL EVALUATION OF ANTINEOPLASTIC ACTIVITY OF HYDROETHANOLIC EXTRACT OF UNRIPE FRUIT OF CARICA PAPAYA LINN USING ANIMAL MODEL
}

\author{
PADMAM PRAVEENA ${ }^{1 *}$, JAYAPALAN PRASANNAKUMARI JETHINLALKHOSH ${ }^{1}$, VICTOR AROKIA DOSS ${ }^{2}$
}

${ }^{1}$ Research and Development Centre, Bharathiar University, Coimbatore, Tamil Nadu, India. ${ }^{2}$ Department of Biochemistry, P S G College of Arts and Science, Coimbatore, Tamil Nadu, India. Email: praveenapadmam@gmail.com

Received: 07 July 2017, Revised and Accepted: 05 September 2017

\section{ABSTRACT}

Objective: This study was undertaken to screen the effect of administration of various doses of hydroethanolic extract of unripe fruit of Carica papaya L. (HEECP) against Dalton's ascitic lymphoma (DAL) in Swiss albino mice.

Methods: DAL cells were injected intraperitoneally $\left(1 \times 10^{6}\right.$ cells $)$ to each mouse and divided into various groups. The animals were treated with various doses (200 mg/kg and $400 \mathrm{mg} / \mathrm{kg}$ ) of HEECP. A standard drug (5-fluorouracil, $20 \mathrm{mg} / \mathrm{kg} /$ day) was also used. The animals were evaluated for hematological and biochemical parameters and were compared with the same parameters in the standard by collecting blood from a retro-orbital blood vessel of mice.

Results: The life spans of the animals were increased. In the DAL tumor control group, the average life span of animals was found to be $45 \%$ whereas, 200 and $400 \mathrm{mg} / \mathrm{kg}$ of test drug showed increase in life span to $67 \%$ and $75 \%$, respectively. Platelets count was significantly (p<0.001) decreased in cancer control group and was brought back to normal after treatment.

Conclusion: These observations suggest that the extract possesses antineoplastic effect against DAL.

Keywords: Carica papaya L, Dalton's ascitic lymphoma, Tumor.

(C) 2017 The Authors. Published by Innovare Academic Sciences Pvt Ltd. This is an open access article under the CC BY license (http://creativecommons. org/licenses/by/4. 0/) DOI: http://dx.doi.org/10.22159/ajpcr.2017.v10i12.21165

\section{INTRODUCTION}

Cancer has now become a leading cause of death among humans. It is characterized by uncontrolled growth and spread of abnormal cells. It refers to a group of diseases which share similar characteristics. Cancer can affect all ages and in both genders. The causes are multifactorial, and the disease process differs at different sites. Even though various anticancer drugs are known we are in continuous search for more effective ones [1]. Cervical cancer, mainly caused by Human Papillomavirus infection, is leading cancer in Indian women and the second most common cancer in women worldwide. It ranks as the $2^{\text {nd }}$ leading cause of female cancer deaths in India. Cervical cancer is the second leading cause of cancer deaths in women aged 15-44 years in India [2]. Plant based medications have now become a significant element of indigenous medical systems around the world. Majority of the plants studied have shown effective medicinal values. Several studies have proven that Carica papaya Linn has commendable medicinal properties. C. papaya belongs to family Caricaceae and is commonly known as papaya in English, Papita in Hindi, and Koppanga in Malayalam. The plant is recognized by its weak and usually unbranched soft stem yielding copious white latex and crowded by a terminal cluster of large and long stalked leaves. It is rapidly growing and can grow up to $20 \mathrm{~m}$ tall. It is cultivated for its fruits. Papain is a proteolytic enzyme which finds numerable industrial uses. It is used in meat tenderizes and chewing gums. The leaves are used for the treatment of malaria, dengue, and jaundice. Both leaves and fruits of C. papaya possess medicinal properties such as anti-inflammatory hypoglycemic, antifertility, abortifacient, hepatoprotective, wound healing, antihypertensive, and antitumor activities [3]. Evidence from several studies suggests that the fruits of $C$. papaya have antifertility properties. Papaya leaves have been seen as a potential source of useful food and drug items. The presence of alkaloids is being effectively exploited as an anti-malaria agent $[4,5]$. According to the book "Nature cure for cancer," there are many reports that cancer sufferers have been healed by drinking papaya leaf concentrate [6]. The crude papaya latex contains an uterotonic principle consisting of a combination of enzymes, alkaloids, flavonoids, and other substances [7]. The vinblastine and vincristine alkaloids obtained from Catharanthus roseus are popularly used for the treatment of patients suffering from leukemia and Hodgkin's disease [8]. The crude proteins from seeds and fruits of $C$. papaya displayed very strong antioxidant and potential cytotoxicity activity [9].

\section{METHODS}

Plant material

C. papaya unripe fruits were collected from in and around Kodakara, Thrissur, and Kerala and were identified and certified by the taxonomist, Botanical Survey of India (BSI), Coimbatore, Tamil Nadu, India (Plant identification no.-BSI/SRC/5/23/2013-14/Tech/683).

\section{Extraction procedure}

Crude plant extracts were extracted by Soxhlet extraction method. About $100 \mathrm{~g}$ of plant material was uniformly packed into a thimble and extracted with $350 \mathrm{ml}$ of $50 \%$ ethanol as solvent. The process of extraction continued till the solvent in siphon tube of an extractor became colorless. The solvent extract was filtered and dried using rotary evaporator. This hydroethanolic fraction of C. papaya L (HEECP) was taken for further studies.

\section{Experimental animals}

Female Swiss albino mice (20-25 g) were procured from animal experimental laboratory, K.M. College of Pharmacy, Uthangudi, Madurai, and used throughout the study. They were housed in micro nylon boxes in a control environment (temp $25 \pm 2^{\circ} \mathrm{C}$ ) and $12 \mathrm{hrs} \mathrm{dark/}$ light cycle with standard laboratory diet and water ad libitum. They were fed on a healthy diet and maintained in a hygienic environment in animal house [10]. The entire study was approved by the Institutional 
Animal Ethical Committee (IAEC) which is certified by the Committee for the Purpose of Control and Supervision of Experiments on Animals (CPCSEA), Ministry of Social Justice and Empowerment, Government of India (IAEC no.:661/02/c/CPCSEA). In this study, Dalton's ascites lymphoma (DAL) cell lines induced cancer in mice was used to evaluate the antineoplastic activity.

\section{Acute toxicity study}

Acute toxicity study was performed according to OECD guidelines 425 (Organization of Economic Cooperation and Development). The rats were fasted overnight and provided with water ad libitum [11]. Following the period of fasting, the animals were treated with the test extract at the dose of $2000 \mathrm{mg} / \mathrm{kg}$ (HEECP) body weight.

\section{Induction of cancer using DAL cells}

DAL cell line was procured from Amala Cancer Research Center, Thrissur, Kerala, and India. The cells were maintained in vivo in Swiss albino mice by intra peritoneal transplantation. While transferring the tumor cells to the grouped animal, the DAL cells were aspirated from peritoneal cavity of the mice using saline. The cell counts were done, and further dilutions were made to attain a count of $1 \times 10^{6}$. This dilution was given intraperitoneally to the animals.

\section{Treatment protocol}

Swiss albino mice were divided into five groups of six animals each. All the animals in four groups were injected with DAL cells $\left(1 \times 10^{6}\right.$ cells per mouse) intraperitoneally, and the remaining one group was maintained as a normal control group [12]. Group I served as the normal control. Group II served as the tumor control. Groups I and II received normal diet and water. Group III served as the positive control and the animals were treated with 5- fluorouracil (5-FU) at $20 \mathrm{mg} / \mathrm{kg}$ i.p. body weight, intraperitoneally. Group IV served as a low dose treatment group and was administered with $200 \mathrm{mg} / \mathrm{kg}$ of HEECP. Group V served as a high dose treatment group and was administered with $400 \mathrm{mg} / \mathrm{kg}$ of HEECP. In this study, drug treatment was given after the 24 hrs of inoculation, once daily for 14 days. On day 15, after 24 hrs of the last dose, blood was withdrawn from each mouse by retro-orbital plexus method if the animal was alive [13]. Hematological parameters such as hemoglobin (Hb) content, red blood cell (RBC) count, total white blood cell (WBC) count, and platelet count were determined. Biochemical parameters such as total cholesterol, triglyceride, aspartate transaminase (AST), alanine transaminase (ALT), and alkaline phosphatase (ALP) were also studied. The animals were followed till death or up to 30 days and all mice from each group were sacrificed. Derived parameters, namely, body weight, life span (\%), and cancer cell count were also determined.

\section{Cancer cell count}

The fluid $(0.1 \mathrm{ml})$ from the peritoneal cavity of each mouse was withdrawn by sterile syringe and diluted with $0.8 \mathrm{ml}$ of ice cold normal saline or sterile phosphate buffer solution and $0.1 \mathrm{ml}$ of Trypan blue $(0.1 \mathrm{mg} / \mathrm{ml})$ and total numbers of the living cells were counted using hemocytometer.

Cellcount $=\frac{\text { Number of cells } \times \text { Dilution }}{\text { Area } \times \text { thickness of liquidfilm }}$

\section{Effect of test drug on survival time}

Except for the normal control group, the remaining groups were inoculated with DAL cells $\left(1 \times 10^{6}\right.$ cells/mouse $)$ intraperitoneally on day " 0 " and treatment with test drug started $24 \mathrm{hrs}$ after inoculation, at a dose of $200 \mathrm{mg} / \mathrm{kg}$ and $400 \mathrm{mg} / \mathrm{kg} /$ day. p.o. The normal and tumor control group was treated with the same volume of $0.9 \%$ sodium chloride solution. All the treatments were given for 14 days. The increase in life span (ILS) of each group, consisting of six mice was noted. The antitumor efficacy of test drug was compared with that of 5-FU (Dabur Pharmaceutical Ltd. India; 5-FU, 20 mg/kg/day, i.p, for 14 days).

\section{Statistical analysis}

The results are expressed as mean \pm standard deviation (SD). Differences between groups were assessed by one-way analysis of variance using the Statistical Package for the Social Sciences (SPSS, Version 16.0 for windows). The group means were compared by Duncan's multiple range test. Values were considered statistically significant when $\mathrm{p}<0.05$.

\section{RESULTS AND DISCUSSION}

\section{Effect on Survival}

The effect of test drug on tumor growth responses was observed and is shown in Fig. 1. In Group II (DAL tumor control), the average life span of animals was found to be $45 \%$ whereas, in Groups III and IV, the test drug showed ILS to $67 \%$ and $75 \%$, respectively. These values were significant $(\mathrm{p}<0.001)$ when compared with cancer control group mice. The average life span of 5 -FU treated was found to be $87 \%$, indicating its potent antitumor nature. The study goes in correlation with the work conducted using Melastoma malabathricum L. leaves against DAL [14].

The antitumor nature of test drug was evidenced by the significant $(\mathrm{p}<0.01)$ reduction of increase in body weight in animals treated with test drug at the dose of 200 and $400 \mathrm{mg} / \mathrm{kg}$ test drug when compared to DAL tumor bearing mice. There was a significant $(p<0.001)$ reduction in viable tumor cell count in Groups III and IV when compared to the DAL tumor control (Fig. 2)

\section{Effect on hematological parameters}

The effect of test drug on hematological parameters in cancer bearing mice is shown in Table 1. The variation in the RBC and $\mathrm{Hb}$ content is shown in Fig. 3. RBC count, $\mathrm{Hb}$ content, and platelets count were significantly $(\mathrm{p}<0.001)$ decreased in cancer control group and were brought back to normal after treatment with various doses of test drug. WBC count was significantly $(\mathrm{p}<0.001)$ increased in the DAL control group and was found to be near normal by the treatment with test drug. In Group I, the total WBC count was found to be $9.31 \pm 0.65$ cells $/ \mathrm{ml} \times 10^{3}$, whereas in Group II it was estimated as $13.28 \pm 1.58$ cells $/ \mathrm{ml} \times 10^{3}$. There was considerable decrease in the treatment groups. However, the standard 5-FU at the dose of $20 \mathrm{mg} / \mathrm{kg}$ body weight produced better result in all these parameters. The agents with antitumor activity tend to decrease the WBC count. This is considered a reliable criterion of their antineoplastic activity [15].

\section{Effect on biochemical parameters}

The effect of test drug on serum liver enzymes and lipid profile in cancer bearing mice is shown in Figs. 4 and 5. In DAL inoculated mice,

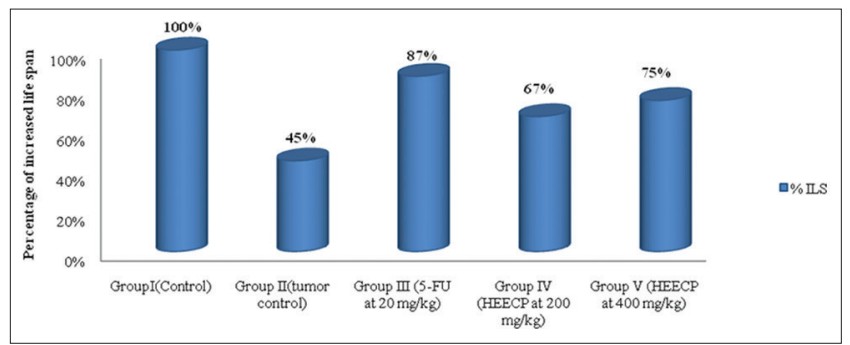

Fig. 1: Percentage of increased life span

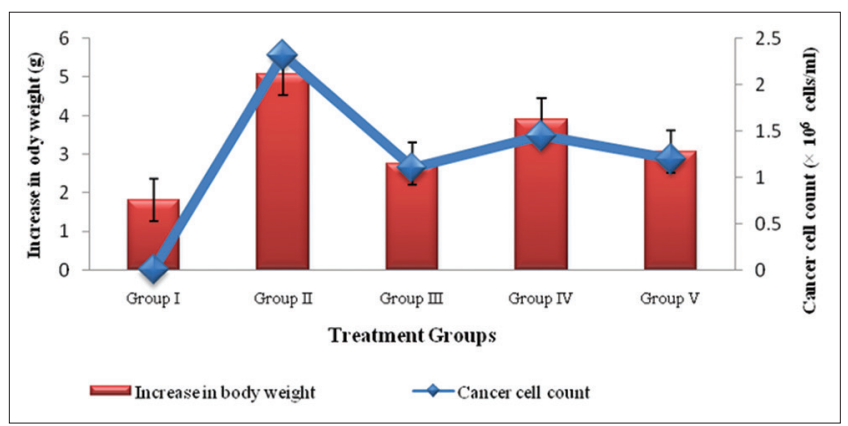

Fig. 2: Effect of hydroethanolic fraction of Carica papaya L. on body weight and cancer cell count 
Table 1: Effect of HEECP on hematological parameters

\begin{tabular}{|c|c|c|c|c|c|c|}
\hline \multirow[t]{2}{*}{ Treatment } & \multirow[t]{2}{*}{ Total WBC cells $/ \mathrm{ml} \times 10^{3}$} & \multirow[t]{2}{*}{ PCV \% } & \multirow{2}{*}{$\begin{array}{l}\text { Platelets } \\
\text { Lakhs } / \mathbf{m m}^{3}\end{array}$} & \multicolumn{3}{|c|}{ Differential count \% } \\
\hline & & & & Lymphocytes & Neutrophils & Monocytes \\
\hline Group I (control) & $9.31 \pm 0.65$ & $14.15 \pm 2.20$ & $3.21 \pm 0.32$ & $74 \pm 3.52$ & $15 \pm 1.7$ & $1 \pm 0$ \\
\hline Group III (5-FU at $20 \mathrm{mg} / \mathrm{kg}$ ) & $10.18 \pm 1.34^{\mathrm{b} * *}$ & $19.81 \pm 2.52^{\mathrm{b} * *}$ & $2.60 \pm 0.69^{\mathrm{b} * *}$ & $73 \pm 4.57^{\mathrm{b} * *}$ & $18 \pm 1.2^{\mathrm{b} * *}$ & $1 \pm 0^{\mathrm{ns}}$ \\
\hline Group IV (HEECP at $200 \mathrm{mg} / \mathrm{kg}$ ) & $12.80 \pm 1.87^{\mathrm{b} *}$ & $25.62 \pm 3.77^{\mathrm{b} *}$ & $1.40 \pm 0.81^{\mathrm{b} *}$ & $67 \pm 3.64^{\mathrm{b} * *}$ & $32 \pm 1.26^{\mathrm{b} * *}$ & $1 \pm 0^{\mathrm{ns}}$ \\
\hline Group V (HEECP at $400 \mathrm{mg} / \mathrm{kg}$ ) & $11.05 \pm 2.25^{\mathrm{b} * *}$ & $21.37 \pm 2.80^{\mathrm{b} * *}$ & $2.54 \pm 0.90^{\mathrm{b} * *}$ & $69 \pm 3.64^{\mathrm{b} * *}$ & $25 \pm 1.45^{\mathrm{b} * *}$ & $1.0 \pm 0^{\text {ns }}$ \\
\hline
\end{tabular}

All values are expressed as mean \pm SD for six animals in each group. ${ }^{* * a}$ Values are significantly different from control (GI) at $\mathrm{p}<0.001, * \mathrm{~b}$ values are significantly different

from cancer control (GII) at $\mathrm{p}<0.01,{ }^{* * b}$ values are significantly different from cancer control (GII) at $\mathrm{p}<0.001$, NS: Non significant

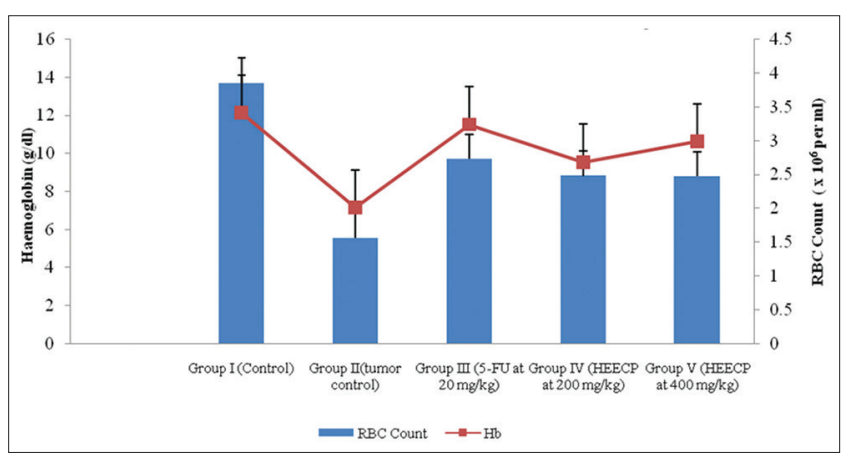

Fig. 3: Effect of hydroethanolic fraction of Carica papaya L. on red blood cell and hemoglobin

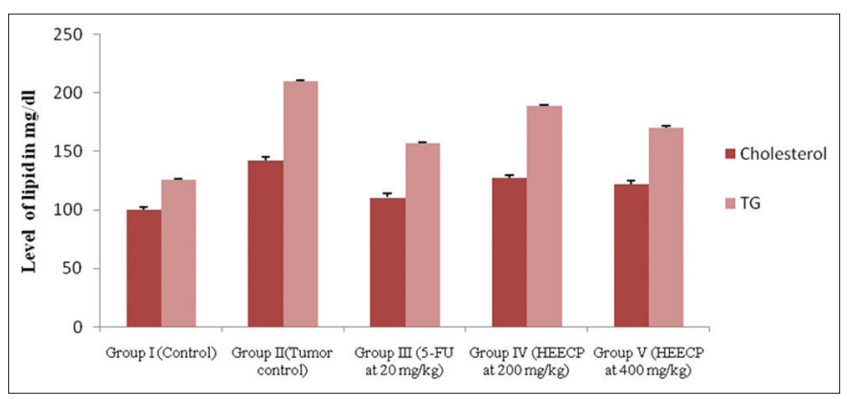

Fig. 4: Effect of administration of hydroethanolic fraction of Carica papaya L. on serum lipid profile

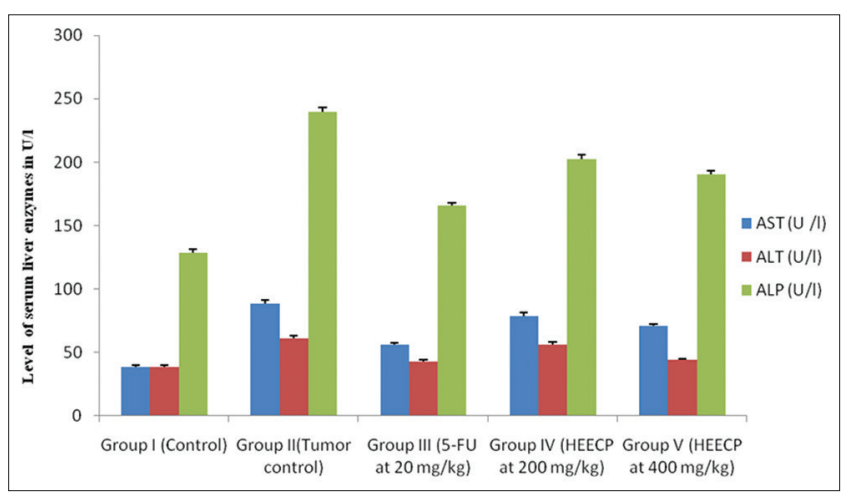

Fig. 5: Effect of administration of hydroethanolic fraction of Carica papaya L. on serum liver enzymes

there was significant $(\mathrm{p}<0.001)$ increase of the level of total cholesterol, triglycerides AST, ALT, and ALP when compared to the normal group. The treatment with test drug at the dose of $200 \mathrm{mg} / \mathrm{kg}$ and $400 \mathrm{mg} / \mathrm{kg}$ body weight reversed these changes toward the normal level. The treatment with standard 5-FU also gave the similar results.

\section{CONCLUSION}

In this study, HEECP showed significant antitumor activity against DAL cell line induced malignant ascites tumor animals. It was noted that even the higher dose of HEECP was found to be less effective than 5-FU which was used as a standard. The life span was prolonged. Prolongation of life span is a valuable criterion for initial evaluation of antitumor activity of any compound [16]. If the compound increases the life span by $25 \%$, it can be considered to have a significant antitumor activity. A decrease in WBC count of blood is also a screening parameter for evaluating the effect of plant derived extracts [17]. The results of survival analysis was also considered for assessing antitumour activity and it was found that HEECP improved the overall survival of the animals.

\section{REFERENCES}

1. Thummar VR, Parasuraman S, Basu D, Raveendran R. Evaluation of in vivo antitumor activity of cleistanthin B in Swiss albino mice. J Tradit Complement Med 2015;6(4):383-8.

2. Bruni L, Barrionuevo-Rosas L, Albero G, Serrano B, Mena M, Gómez D, et al. ICO Information Centre on HPV and Cancer (HPV Information Centre), Human Papillomavirus and Related Diseases in India, Summary Report 15, December; 2016.

3. Anjum V, Ansari SH, Naquvi KJ, Arora P, Ahmad A. Development of quality standards of Carica papaya Linn leaves. Sch Res Libr 2013;5(2):370-6

4. Bonsu AK. The Power of Garlic. Buea, Cameroon: Cardiovascular Disease Prevention Association; 1999. p. 72.

5. Okwu DE, Okwu ME. Chemical composition of Spondias mombin plants. J Sustain Agric Environ 2004;6:140-7.

6. Bakhru HK. Nature Cure for Cancer. $1^{\text {st }}$ ed. Delhi: Jaico Publishing House; 2008. p. 1-2

7. Cherian T. Effect of papaya latex extract on gravid and non-gravid rat uterine preparations in vitro. J Ethnopharmacol 2000;70(3):205-12.

8. Kaur R, Arora S. Alkaloids-important therapeutic secondary metabolites of plant origin. J Crit Rev 2015;2(3):1-8

9. Khor ES, Wong NK. Comparison study of therapeutic properties of proteins and secondary metabolites from Carica papaya. Int J Pharm Pharm Sci 2016;8(4):153-8.

10. Unnikrishnan MC, Kuttan R. Tumor reducing and anti-carcinogenic activity of selected species. Cancer Lett 1990;51:85-9.

11. Ecobichon DJ. The Basis of Toxicology Testing. $2^{\text {nd }}$ ed. New York: CRC Press; 1997. p. 43-60

12. Sathiyanarayanan L, Shinnathambi, Arulmozi S, Chidhambarnathan N. Anti-carcinogenic activity of Leptadenia reticulataI against Dalton's ascitic lymphoma. Iran J Pharmacol Toxicol 2006;6:133-6.

13. Parasuraman S, Raveendran R, Kesavan R. Blood sample collection in small laboratory animals. J Pharmacol Pharmacother 2010;1(2):87-93.

14. Clarkson BD, Burchenal JH. Preliminary screening of antineoplastic drugs. Prog Clin Cancer 1965;1:625-9.

15. Oberling $\mathrm{C}$, Guerin $\mathrm{M}$. The role of viruses in the production of cancer. Adv Cancer Res 1954;2:353-423.

16. Balamurugan K, Nishanthini A, Mohan VR. Anticancer activity of ethanol extract of Melastoma malabathricum L. Leaf against Dalton ascites lymphoma. J Pharm Sci Res 2013;5:11-114.

17. Saroja M, Annapoorani S. Antitumor activity of methanolic extract of Terminalia catappa leaves against Ehrlich ascites induced carcinoma in mice. Int Res J Pharm 2011:2:253-4 